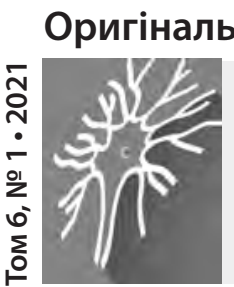

www. painmedicine.org.ua

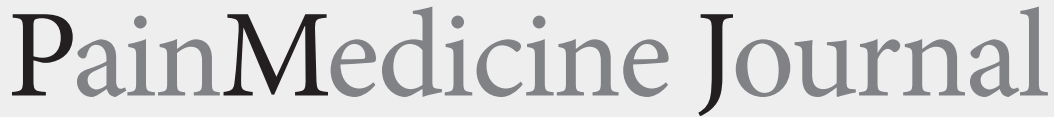

Медицина Болю // Медицина Боли

Міждисциплінарний • Науково-практичний журнал

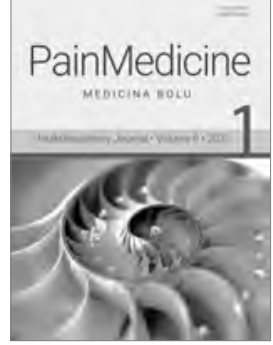

DOI: 10.31636/pmjua.v6i1.3

\title{
Rationale for preoperative (versus postoperative) administration of meloxicam for acute pain management and assessment of satisfaction in patients with femoroacetabular impingement who underwent hip arthroscopy
}

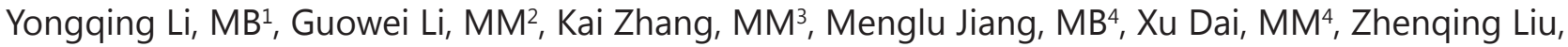
$\mathrm{MB}^{4}$, Ou Wang, $\mathrm{MB}^{3}$

1Department of Anesthesiology, Shanghai Liqun Hospital, Putuo District, Shanghai, China
2Department of Anesthesiology, Wuxi Fifth People's Hospital Affiliated to Jiangnan University, Wuxi, China
${ }^{3}$ Department of Orthopedics, Shanghai Liqun Hospital, Putuo District, Shanghai, China
${ }^{4}$ Department of Anesthesiology, Wuxi No.9 People's Hospital Affiliated to Soochow University, Wuxi, China

Declarations

Yongqing Li and Guowei Li contributed equally to this work.

Running title

Meloxicam in FAI patients who underwent $H A$.

Acknowledgements

This study was supported by Wuxi Science and Technology Development Medical and Health Guidance Plan (No: NZ2019038).

Conflicts of Interest

The authors of this work have nothing to disclose.

\section{Abstract}

Objective: This study is aimed to compare the analgesic effect and safety of preoperative (versus postoperative) meloxicam administration in femoroacetabular impingement (FAI) patients who underwent hip arthroscopy (HA).

Methods: Totally, 136 FAI patients who scheduled for HA were recruited, then they were randomly assigned to preoperative administration (PREA) group (orally meloxicam $7.5 \mathrm{mg}$ in $12 \mathrm{~h}$, $24 \mathrm{~h}$ before operation, then orally $7.5 \mathrm{mg} / \mathrm{d}$ from $12 \mathrm{~h}$ to Day 7 after operation; $N=68$ ) or postoperative administration (POSA) group (orally meloxicam $7.5 \mathrm{mg} / \mathrm{d}$ from $12 \mathrm{~h}$ to Day 7 after operation; $N=68)$ in 1:1 ratio. Furthermore, pain visual analog scale (VAS) score, patient satisfaction score, Harris hip score (HHS) and adverse events were assessed. Besides, the accumulated pethidine consumption for rescuing analgesia was calculated. 
Results: Acute pain VAS score at rest (Day1 - Day2) and pain VAS score at motion (Day1 - Day3) were decreased, meanwhile short-term patient satisfaction score (Day1-Day3) was increased in PREA group compared with POSA group; however, these scores in long-term period were of no difference between PREA group and POSA group (Day3-Month3). Furthermore, accumulated pethidine consumption on Day3 and Day7 were attenuated in PREA group compared with POSA group. Additionally, HHS at any assessed time points (Day7-Month3) did not differ between two groups. Besides, no difference in the incidence of adverse events was found between two groups.

Conclusions: Preoperative meloxicam administration displays superior efficacy in short-term pain control, patient satisfaction improvement and attenuated consumption of rescue analgesia over postoperative meloxicam administration in FAI patients who underwent HA.

Key words: Meloxicam, femoroacetabular impingement, hip arthroscopy, efficacy, safety.

\section{Introduction}

Femoroacetabular impingement (FAI) is characterized by abnormal morphology of femoral head-neck or acetabulum that leads to impingement $[1,2]$. The main symptom of FAI is pain, meanwhile, FAI might also lead to mechanical symptoms (such as articular stiffness and objective hip instability), articular lesions (including hip osteoarthritis), and even disability [3]. Current treatments for FAI mainly consist of non-operative management (such as rest, physiotherapy and administration of nonsteroidal anti-inflammatory drugs (NSAIDs)) and surgical management (such as open surgery and hip arthroscopy (HA)) [4, 5]. Among these treatments, HA is becoming more popular for it is minimally invasive, which corrects hip shape abnormalities and prevents intraarticular injury $[4,6]$. However, FAI patients who underwent HA still suffer from postoperative pain that rises the risk of complications and hinders hip joint recovery [6]. In regular open surgery, strong opioid analgesics have been frequently administrated to control postoperative pain; while in minimal invasive surgery (such as HA), weak opioid and NSAIDs are preferred, while their administration are related to several adverse events (such as respiratory suppression, nausea and vomiting) and potential addiction [7].

Meloxicam is a kind of selective NSAIDs, which presents similar analgesic, anti-inflammatory effects, and reduces the incidence of gastric and renal disorders compared to non-selective NSAIDs [8]. Although meloxicam has been widely administrated for treating osteoarthritis, rheumatoid arthritis and other pain syndromes caused by osteoarticular lesions, the effect of preoperative meloxicam administration on managing postoperative pain in patients with osteoarticular lesions is not discovered until recent $[9,10]$. For instance, one recent study suggests that compared with postoperative meloxicam administration, preoperative meloxicam administration attenuates acute pain and reduces additional analgesia consumption in patients who underwent arthroscopic knee surgery
[11]. Moreover, another interesting study reveals that preoperative meloxicam administration has better effect than postoperative meloxicam administration on controlling acute postoperative pain, while it presents similar effect on the incidence of adverse events and knee function recovery to postoperative meloxicam administration in patients who underwent arthroscopic knee surgery [12]. However, whether preoperative meloxicam administration would also present good analgesic effect and tolerance in FAI patients after HA is not clear.

Therefore, we performed this randomized, controlled study and aimed to compare the analgesic effect and safety of preoperative versus postoperative meloxicam administration in FAI patients who underwent HA.

\section{Methods}

\section{Study population}

This randomized, controlled study consecutively recruited 136 FAI patients who scheduled for HA between January 2016 and December 2019. The inclusion criteria for eligible patients comprised of: (a) diagnosed as FAI based on clinical manifestation and imagological diagnosis; (b) unilateral lesion; (c) age older than 18 years; (d) scheduled for HA; (e) willing to comply with study intervention. The exclusion criteria included: (a) allergic or contraindication to study drug; (b) known hip osteoarthritis or other diseases of the femur or hip joint; (c) physical conditions were not suitable for HA; (d) administered with analgesic drugs within a week prior to recruitment; (e) nervous system diseases or dysfunctions; (f) history of hip surgery or interventional therapy; (g) history of corticosteroid or hyaluronic acid injection treatment within 3 months; (h) female patients in pregnancy or lactating. The approval for the current study was obtained from the Institutional Review Board. The signed informed consent was collected from each patient before they were included in the study. 


\section{Random grouping and treatment}

After enrollment, eligible patients were randomly assigned to preoperative administration (PREA) group $(\mathrm{N}=68)$ or postoperative administration (POSA) group $(\mathrm{n}=68)$ by blocked randomization method in a 1:1 ratio. HA was managed as described previously [13]. In the PREA group, meloxicam was administered as follows: 7.5 $\mathrm{mg}$ (oral) at $24 \mathrm{~h}$ before operation, $7.5 \mathrm{mg}$ (oral) at $12 \mathrm{~h}$ before operation, and then $7.5 \mathrm{mg}$ (oral) once a day from $12 \mathrm{~h}$ after operation to day 7 after operation. In the POSA group, meloxicam was administered as follows: $7.5 \mathrm{mg}$ (oral) once a day from $12 \mathrm{~h}$ after operation to day 7 after operation. If there was intolerable pain within 7 days after operation, pethidine was administered for the patients by intramuscular injection as appropriate. The dosage of used pethidine for rescue analgesia was required to be documented in deatil. Furthermore, considering the postoperative heterotopic ossification risk, all patients both in the PREA group and POSA group received meloxicam $7.5 \mathrm{mg}$ (oral) once a day from day 8 to month 1 after operation.

\section{Assessment}

The baseline demographics and disease-related information were documented, which included age, gender, side of lesion and FAI type. The study outcome assessment comprised of pain score at rest and at motion, patient satisfaction score, Harris hip score (HHS), pethidine consumption and adverse events. For the pain assessment of patients, the $10-\mathrm{cm}$ pain visual analog scale (VAS) was adopted, which had score range of 0 to 10: 0 indicated no pain; 10 indicated the intolerable pain. The pain VAS score was evaluated at rest and at motion, respectively, which was performed prior to operation, then on the postoperative day 1 (D1), day 2 (D2), day 3 (D3), day 7 (D7), at month 1 (M1) and month 3 (M3), respectively. The patient's satisfaction score (ranging from 0 to 10 , where a higher score indicated a higher satisfaction) was evaluated on the postoperative D1, D2, D3, D7, M1 and M3, respectively. HHS was assessed before operation, then on D7, M1 and M3, respectively. HHS was a comprehensive score for evaluation of hip function recovery, including pain, function, absence of deformity, and range of movement. A higher HHS was associated with a better function recovery [14]. In addition, the accumulated pethidine consumption on D3 and D7 was calculated in the outcome assessment, respectively. Adverse events occurred during the study were recorded as well.

\section{Sample size calculation}

Sample size estimation was conducted according to a previous study [15]. The hypothetic mean and standard deviation (SD) of pain VAS score at rest on D1 was $5.0 \pm 1.5$ in PREA group and $6.0 \pm 1.5$ in POSA group. The null hypothesis was: Mean1=Mean2, and the alternative hypothesis was: Mean $1 \neq$ Mean 2 . The power was set as $95 \%$, and the significance level $(\alpha)$ was set as $5 \%$. Determined by the two-sided two-sample t-test, the required minimum sample size was 60 in each group, which was calculated by PASS V11.0 software (NCSS, Kaysville, Utah, USA). Taking into account the possibility of a loss rate of at least $10 \%$, the final sample size was set to 68 in each group, with a total sample size of 136 .

\section{Statistical analysis}

All eligible patients who participated the study randomization were included in the study analysis based on intention-to-treat (ITT) principle. For the patients who early quitted the study, last observation carried forward (LOCF) method was used for processing the lost assessment data. SPSS 22.0 (IBM, Chicago, Illinois, USA) and GraphPad Prism 7.01 (GraphPad Software Inc., San Diego, California, USA) were used for data analysis and graph plotting. Data were described as mean and standard deviation (SD) or count (percentage). Difference analysis was completed by Student's t test, Chi-square test or Fisher's exact test. Statistical significance was set as $P$ value $<0.05$.

\section{Results}

\section{Study flow}

A total of 200 FAI patients were screened for eligibility and 64 patients were excluded (including 49 patients who did not met the inclusion criteria or met the exclusion criteria, and 15 patients who disagreed to sign informed consents). Subsequently, 136 FAI patients planning to receive $\mathrm{HA}$ were recruited and randomized as a ratio of 1:1 into PREA group $(\mathrm{N}=68)$ and POSA group $(\mathrm{N}=68)$. Meloxicam administration was initiated before HA in the PREA group, while its administration was initiated after HA in the POSA group. Outcomes were assessed in both groups, which included pain VAS score at rest and at motion, patient satisfaction score, HHS, pethidine consumption and adverse events. During the follow-up period, 5 patients withdrew from the study in the PREA group (including 3 patients who violated the protocol and $2 \mathrm{pa}-$ tients who lost follow-up), 6 patients withdrew from the study in the POSA group (including 4 patients who violated the protocol and 5 patients who lost follow-up). Finally, all 136 recruited patients were included in the analysis based on the ITT principle (Fig. 1).

\section{Basic characteristics}

The POSA group had a mean age of $34.4 \pm 7.3$ years with $43(63.2 \%)$ males and $25(36.8 \%)$ females. Meanwhile, the PREA group had a mean age of $35.0 \pm 7.7$ years with 


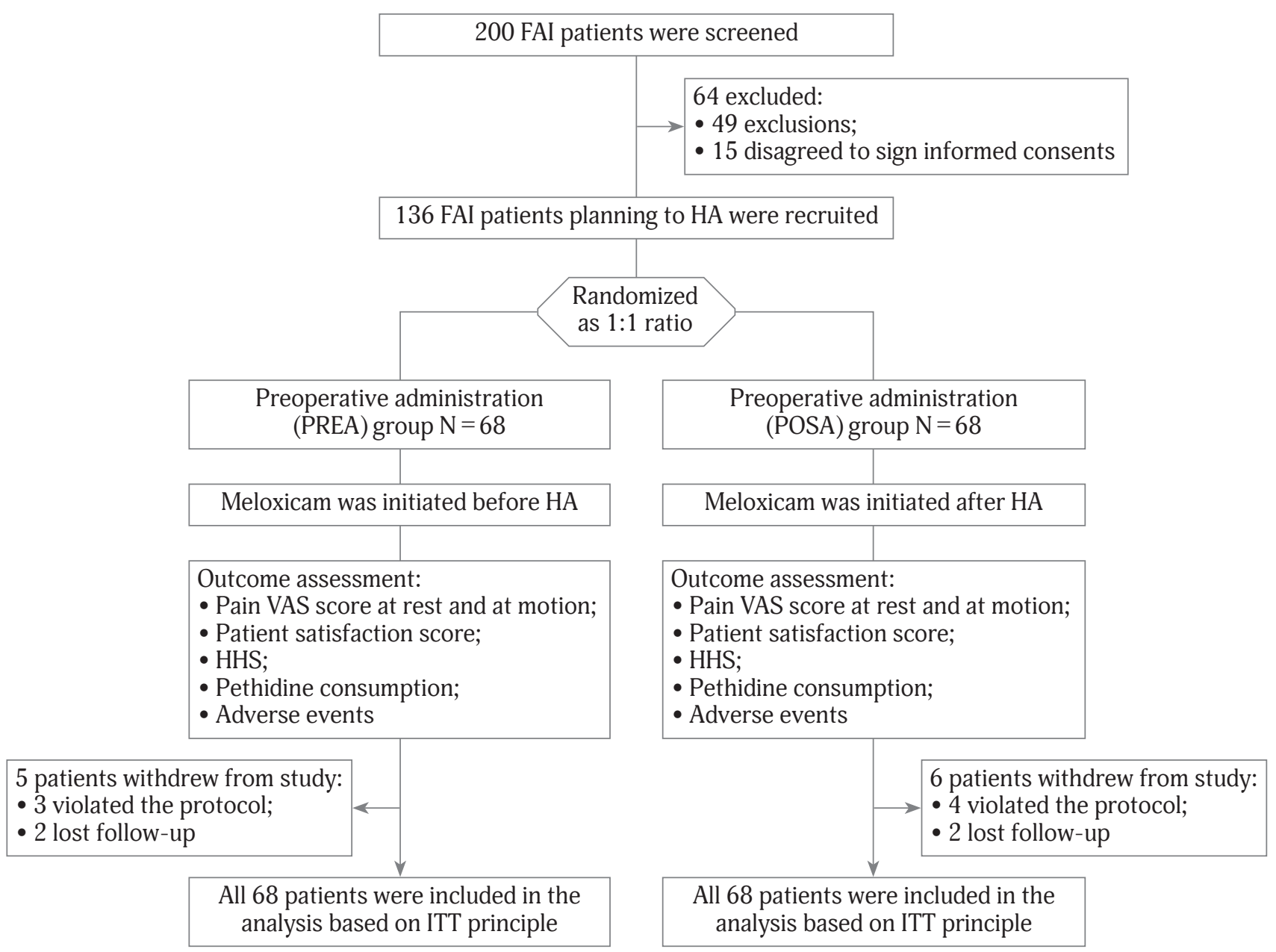

Fig. 1. Flow chart of this study. FAI: femoroacetabular impingement; HA: hip arthroscopy; VAS: visual analog scale; HHS: Harris hip score; ITT: intention-to-treat

$38(55.9 \%)$ males and 30 (44.1\%) females. Further comparison analyses showed that no difference was found in age, gender, lesion location or FAI type between the two groups (all $P>0.05$ ) (Table 1).

\section{Pain VAS score at rest and at motion}

Pain VAS score at rest on D1 $(P=0.007)$ and D2 $(P=0.042)$ was reduced in the PREA group compared with POSA group, while pain VAS score at rest prior to HA, on D3, D7, M1 and M3 remained similar between the two groups (all $P>0.05$ ) (Fig. 2A). Meanwhile, pain VAS score at motion was reduced on $\mathrm{D} 1(P=0.005), \mathrm{D} 2(P=0.003)$ and D3 $(P=0.017)$ in the PREA group compared with POSA group, however, no difference was found in it prior to HA, on D7, M1 and M3 between the two groups (all $P>0.05$ ) (Fig. 2B). Besides, subgroup analyses showed that preoperative meloxicam administration had better effect on reducing acute pain at rest and at motion in patients older than or equal to 35 years and male patients (Supplementary Fig. 1A-1H).

\section{Patient satisfaction score}

Patient satisfaction score on D1 $(P=0.012)$, D2 $(P=0.018)$ and D3 $(P=0.033)$ were elevated in PREA group compared with POSA group; however, no difference was found in patient satisfaction score on D7, M1 or M3 between the two groups (all $P>0.05$ ) (Fig. 3). Additionally, subgroup analysis revealed that preoperative meloxicam administration had better effect on promoting short patient satisfaction in patients older than or equal to 35 years and male patients (Supplementary Fig. 2A-2D).

\section{Accumulated pethidine consumption on D3 and D7}

Accumulated pethidine consumption on D3 $(P=0.045)$ and D7 $(P=0.032)$ were both reduced in PREA group compared with POSA group (Fig. 4A, B).

\section{Adverse events}

The main adverse events were nausea, constipation, vomiting, dizziness and drowsiness. Meanwhile, comparison analyses showed that no difference was found in the inci- 
Table 1. Comparison of basic characteristics between POSA group and PREA group

\begin{tabular}{llll}
\hline \multicolumn{1}{c}{ Parameters } & POSA group $(\mathbf{N}=68)$ & PREA group (N=68) & $P$ value \\
\hline Age (years), mean \pm SD & $34.4 \pm 7.3$ & $35.0 \pm 7.7$ & 0.657 \\
\hline Gender, No. (\%) & & 0.382 \\
\hline Male & $43(63.2)$ & $38(55.9)$ & \\
\hline Female & $25(36.8)$ & $30(44.1)$ & 0.385 \\
\hline Lesion location, No. (\%) & & \\
\hline Right & $31(45.6)$ & $26(38.2)$ & 0.330 \\
\hline Left & $37(54.4)$ & $42(61.8)$ & \\
\hline FAI type, No. (\%) & & \\
\hline Cam & $30(44.1)$ & $35(51.5)$ & \\
\hline Pincer & $25(36.8)$ & $17(25.0)$ & \\
\hline Mixed & $13(19.1)$ & $16(23.5)$ & \\
\hline
\end{tabular}

FAI, femoroacetabular impingement; POSA, postoperative administration; PREA, preoperative administration; $\mathrm{SD}$, standard deviation.
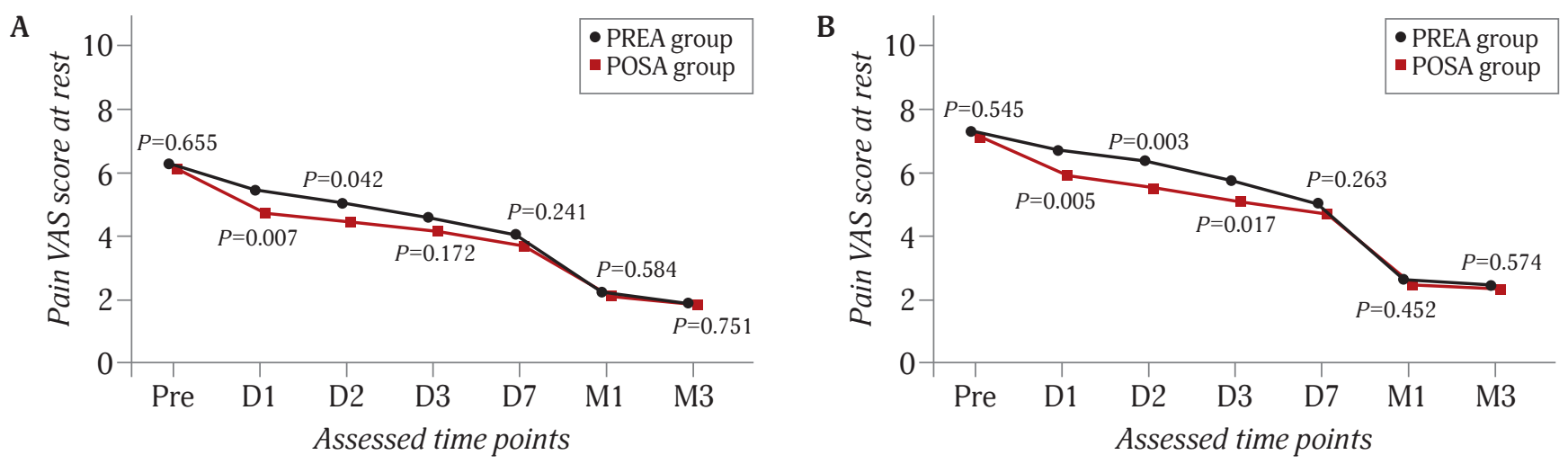

Fig. 2. Comparisons of pain VAS score at rest (A) and pain VAS score at motion (B) prior to HA, on D1, D2, D3, D7, M1 and M3 between PREA group and POSA group. VAS: visual analog scale; pre: prior to hip arthroscopy; D1, day 1; D2, day 2; D3, day 3; D7, day 7; M1, month 1; M3, month 3; HA: hip arthroscopy; PREA: preoperative administration; POSA: postoperative administration

dence of these adverse events between PREA group and POSA group (all $P>0.05$ ) (Table 2).

\section{HHS score}

HHS score prior to HA, on D7, M1 and M3 remained similar between PREA group and POSA group (all $P>0.05$ ) (Fig. 5).

\section{Discussion}

In this current study, the main findings were summarized below: (i) Preoperative meloxicam administration attenuated short-term pain, improved patient satisfaction score and reduced need for rescue analgesia compared with postoperative meloxicam administration in FAI patients who underwent HA; (ii) Preoperative meloxicam administration exhibited no improvement in long-term hip function recovery (reflected by HHS score) compared with postoperative meloxicam administration in FAI patients who underwent HA; (ii) Preoperative meloxicam administration was equally tolerable compared with postoperative meloxicam administration in FAI patients who underwent HA.

Earlier literatures illustrate that preoperative meloxicam administration is more effective in mitigating shortterm postoperative pain and reducing consumption of rescue analgesia compared to postoperative meloxicam 
A

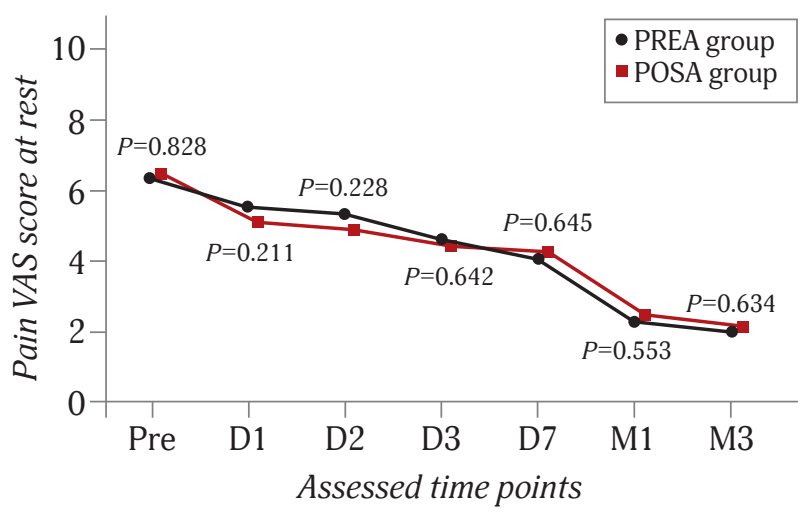

B

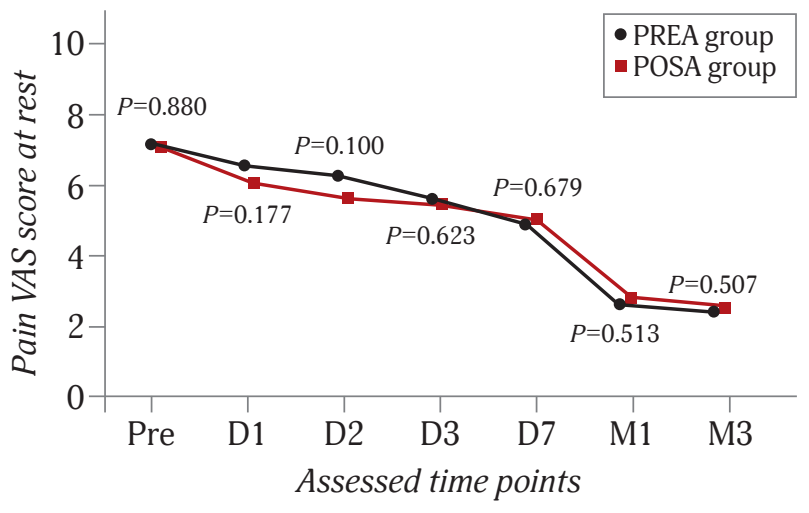

Male
C

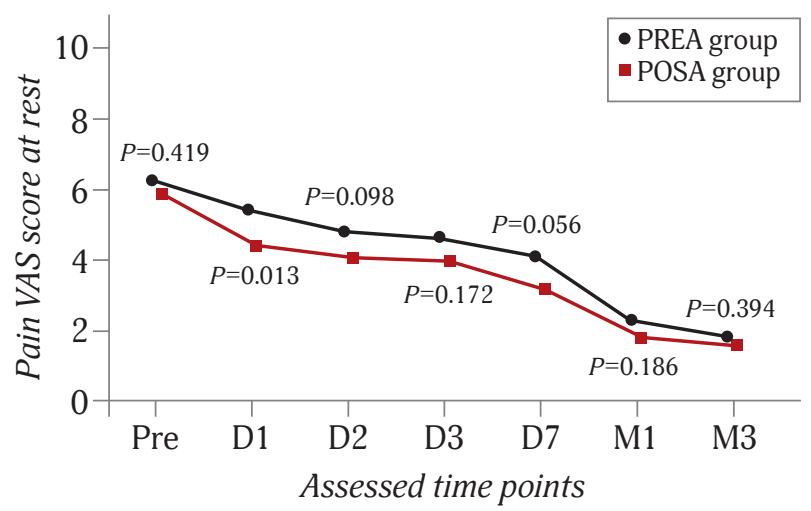

D

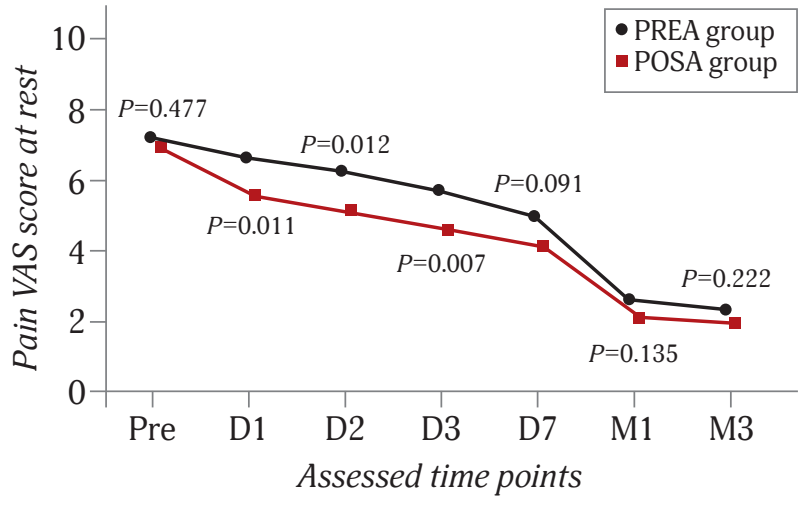

Female
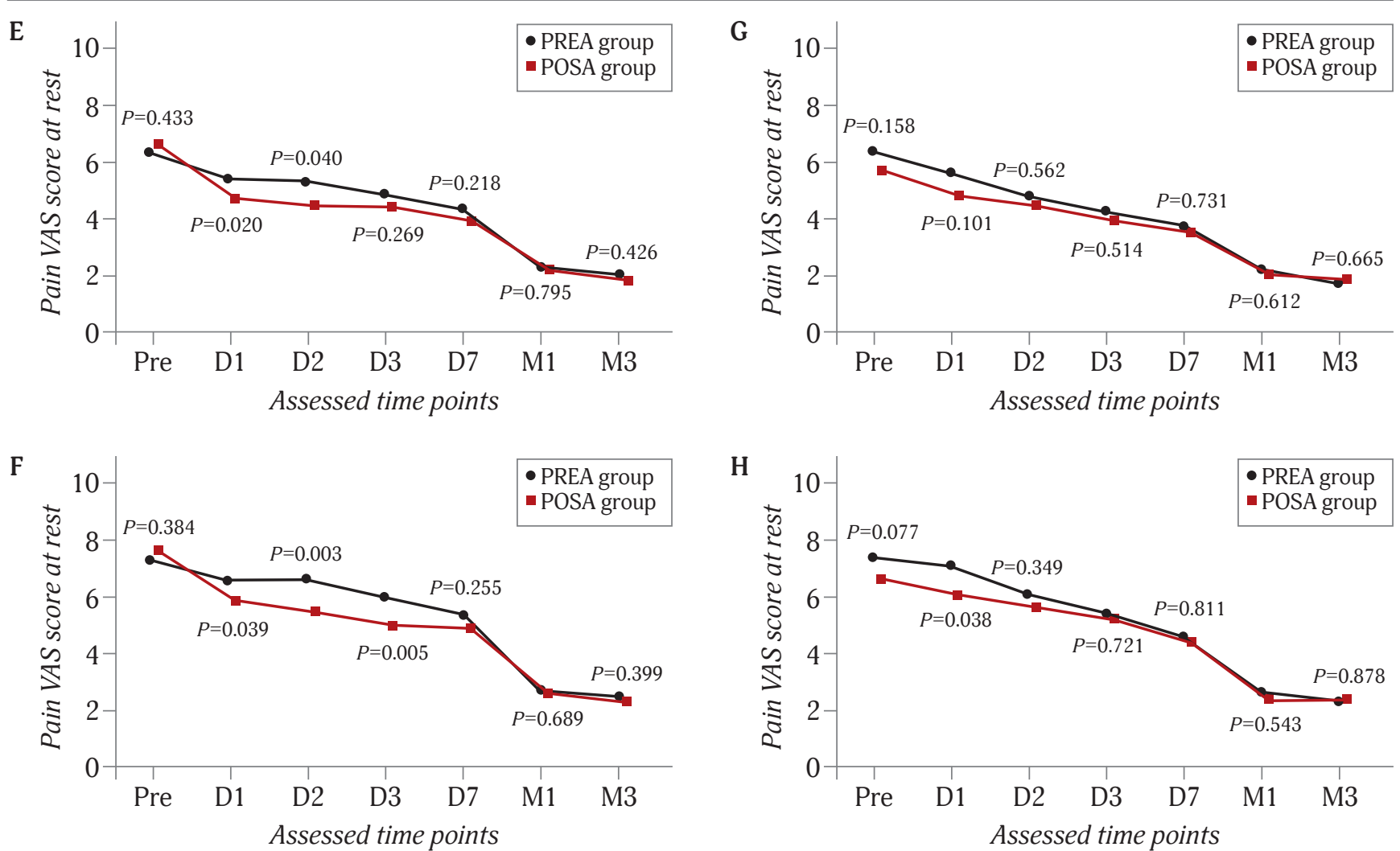

Supplementary Fig. 1. Subgroup analysis of pain VAS score at rest and at motion prior to HA, on D1, D2, D3, D7, M1 and M3 in PREA group and POSA group. In patients younger than 35 years (A, B), patients older than or equal to 35 years (C, D), male patients (E, F) or female patients (G, H): Comparisons of pain VAS score at rest and pain VAS score at motion prior to HA, on D1, D2, D3, D7, M1, M3 between PREA group and POSA group. VAS: visual analog scale; pre: prior to hip arthroscopy; D1, day 1; D2, day 2; D3, day 3; D7, day 7; M1, month 1; M3, month 3; PREA: preoperative administration; POSA: postoperative administration; HA: hip arthroscopy 


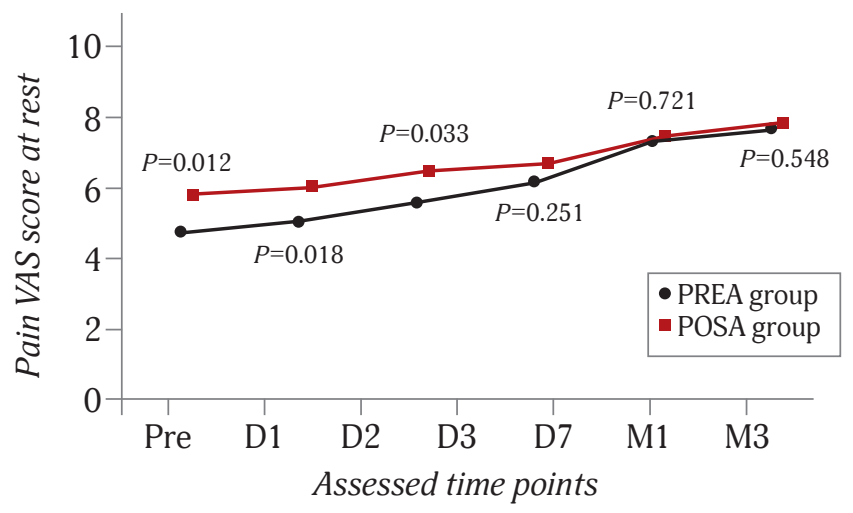

Fig. 3. Comparisons of patient satisfaction score on D1, D2, D3, D7, M1 and M3 between PREA group and POSA group. D1, day 1; D2, day 2; D3, day 3; D7, day 7; M1, month 1; M3, month 3; PREA: preoperative administration; POSA: postoperative administration

administration in patients received arthroscopic knee surgery $[11,12]$. Whereas for FAI patients who underwent HA, no related evidence was identified. In this current study, it was observed that preoperative meloxicam administration reduced short-term postoperative pain, decreased the need for rescue analgesia and improved patient satisfaction score compared with postoperative meloxicam administration in FAI patients who underwent HA. The possible explanations might involve that: (i) Owning to the nature of oral meloxicam with poor dissolution rate and slow onset of action, FAI patients who received meloxicam treatment before HA probably achieved the steady-state of blood meloxicam concentration and the optimal analgesic effectiveness earlier compared with those patients who received meloxicam treatment only after HA, hence, preoperative meloxicam administration was more effective in attenuating short-term pain compared with postoperative meloxicam administration in FAI patients after HA [1, 4, 8, 16]. (ii) Preoperative meloxicam administration might potentially block the transmission of HA-induced noxious stimuli from peripheral system to the central nervous system and prevent the activation of pain-related pathways within the central nervous system, which subsequently reduced the magnitude of postoper-

Age $<35$ years

Age $\geq 35$ years
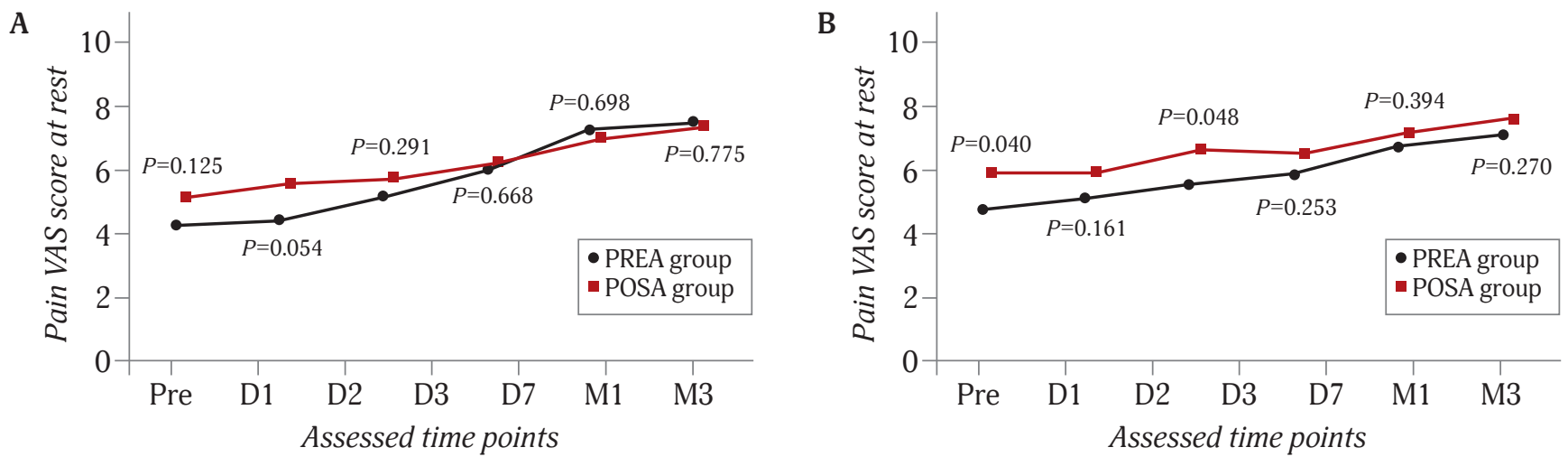

Male

Female
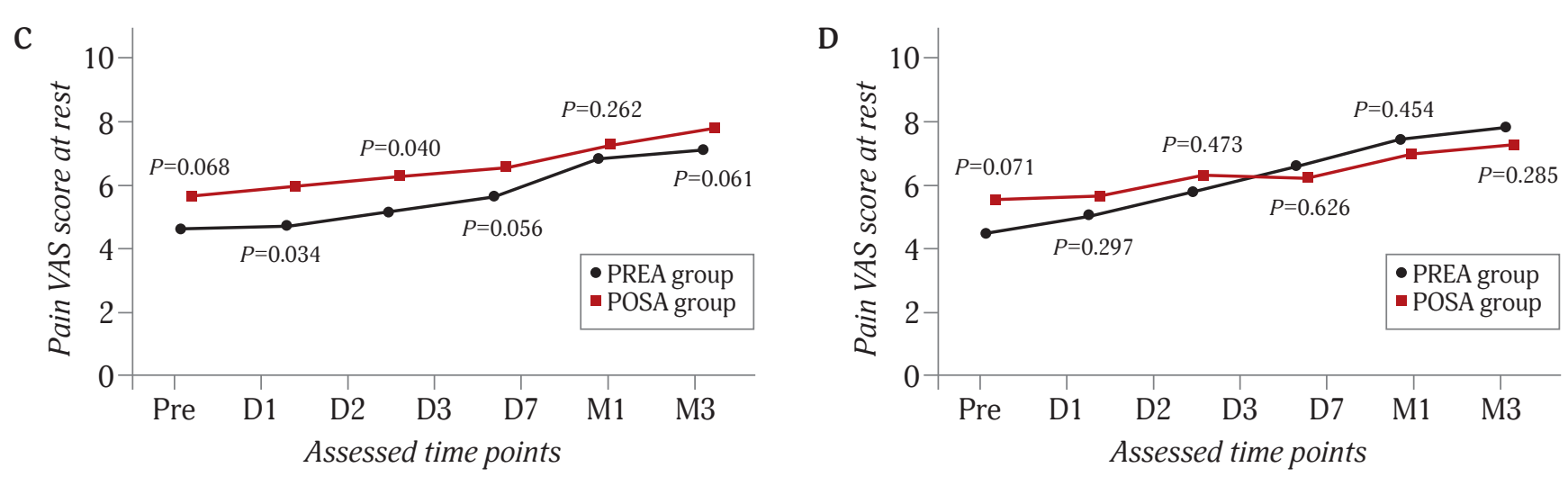

Supplementary Fig. 2. Subgroup analysis of patient satisfaction score on D1, D2, D3, D7, M1 and M3 in PREA group and POSA group. In patients younger than 35 years (A), patients older than or equal to 35 years (B), male patients (C) or female patients (D): Comparisons of patient satisfaction score on D1, D2, D3, D7, M1 and M3 between PREA group and POSA group. D1, day 1; D2, day 2; D3, day 3; D7, day 7; M1, month 1; M3, month 3; preoperative administration; POSA: postoperative administration. 
A

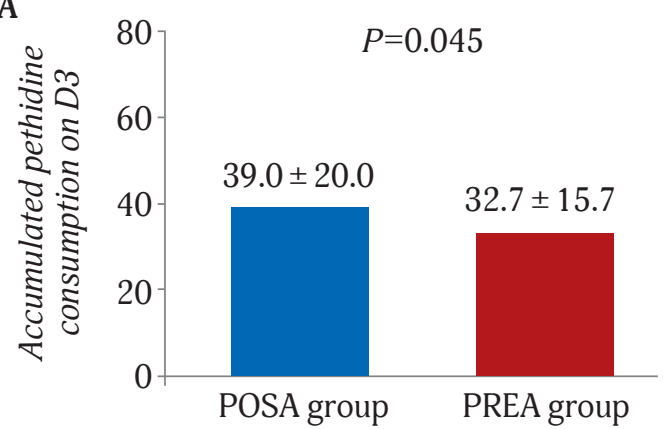

B

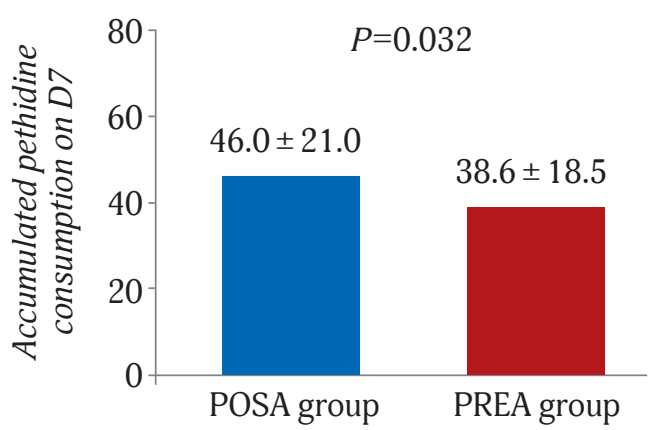

Fig. 4. Comparisons of accumulated pethidine consumption on D3 (A) and accumulated pethidine consumption on D7 (B) between PREA group and POSA group. D3, day 3; D7, day 7; PREA, preoperative administration; POSA, postoperative administration

Table 2. Comparison of adverse events between POSA group and PREA group

\begin{tabular}{llll}
\multicolumn{1}{c}{ Parameters } & \multicolumn{1}{c}{ POSA group $(\mathbf{N}=68)$} & PREA group $(\mathbf{N}=68)$ & $P$ value \\
\hline Nausea, No. $(\%)$ & $16(23.5)$ & $11(16.2)$ & 0.390 \\
\hline Constipation, No. $(\%)$ & $11(16.2)$ & $9(13.2)$ & 0.809 \\
\hline Vomiting, No. $(\%)$ & $5(7.4)$ & $3(4.4)$ & 0.718 \\
\hline Dizziness, No. $(\%)$ & $3(4.4)$ & $1(1.5)$ & 0.619 \\
\hline Drowsiness, No. $(\%)$ & $2(2.9)$ & $1(1.5)$ & 1.000 \\
\hline
\end{tabular}

POSA, postoperative administration; PREA, preoperative administration.

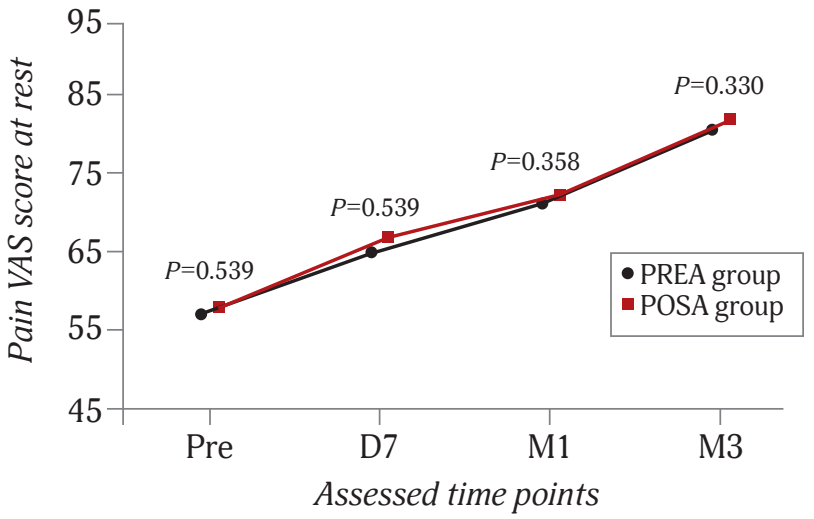

Fig. 5. Comparisons of Harris hip score prior to HA, on D7, M1, M3 between PREA group and POSA group. D7, day 7; M1, month 1; M3, month 3; PREA, preoperative administration; POSA, postoperative administration; HA: hip arthroscopy

ative pain, thus, FAI patients who received preoperative meloxicam treatment had less postoperative pain than these patients who received postoperative meloxicam treatment $[17,18]$. (iii) As discussed above, preoperative meloxicam administration was more effective in relieving short-term pain after HA than postoperative meloxicam administration, which devoted to decreased need for rescue analgesia and higher satisfaction in FAI patients after HA [17-19].
One preceding study elucidates that long-term knee joint function is of no difference between preoperative meloxicam administration and postoperative meloxicam administration in the management of patients who underwent arthroscopic knee surgery [12]. While no relevant study was found in FAI patients who underwent HA. In this current study, it was disclosed that preoperative meloxicam administration showed no improvement in long-term hip function recovery compared with postoperative meloxicam administration in FAI patients after HA. The potential reason was listed as below: HA procedure and rehabilitation after HA but not pain relief were the key elements for long-term hip function recovery in FAI patients after HA, therefore, similar hip function recovery was observed between patients who received preoperative meloxicam treatment and patients received postoperative meloxicam treatment.

As for safety, nausea, drowsiness, dizziness, constipation and vomiting are common while tolerant adverse events in meloxicam-treated patients [8, 11, 12, 19]. In this current study, it was shown that the incidence of these adverse events after HA (including nausea, constipation, vomiting, dizziness and drowsiness) were of no difference between FAI patients who received preoperative meloxicam treatment and those who received postoperative meloxicam treatment, which indicated that preoperative meloxicam administration was equally tolerable 
compared with postoperative meloxicam administration in FAI patients after HA.

Nevertheless, some potential limitations in this current study were elucidated as below: Firstly, the relatively small sample size of recruited FAI patients who scheduled for HA $(\mathrm{N}=136)$ might potentially attenuate the statistical power of analyses. Secondly, pain VAS score was a subjective measure of pain intensity by patients themselves, which probably resulted in subjective biases. Lastly, as this current study was not a double-blinded study, potential biases might exist regarding clinicians' assessment and patients' self-reported outcomes.

To sum up, preoperative meloxicam administration displays superior efficacy in short-term pain control, patient satisfaction improvement and attenuated consumption of rescue analgesia, while it does not improve long-term hip function recovery and shows equally tolerance over postoperative meloxicam administration in FAI patients who underwent HA.

\section{References}

1. Egger AC, Frangiamore S, Rosneck J. Femoroacetabular Impingement: A Review. Sports Medicine and Arthroscopy Review [Internet]. Ovid Technologies (Wolters Kluwer Health); 2016 Dec;24(4):e53-e58. Available from: https://doi. org/10.1097/jsa.0000000000000126.

2. Ghaffari A, Davis I, Storey T, Moser M. Current Concepts of Femoroacetabular Impingement. Radiologic Clinics of North America [Internet]. Elsevier BV; 2018 Nov;56(6):965-82. Available from: https://doi.org/10.1016/j.rcl.2018.06.009.

3. Pun S, Kumar D, Lane NE. Review: Femoroacetabular Impingement. Arthritis \& Rheumatology [Internet]. Wiley; 2014 Dec 27;67(1):17-27. Available from: https://doi.org/10.1002/ art.38887.

4. Papalia R, Del Buono A, Franceschi F, Marinozzi A, Maffulli N, Denaro V. Femoroacetabular impingement syndrome management: arthroscopy or open surgery? International Orthopaedics [Internet]. Springer Science and Business Media LLC; 2011 Dec 22;36(5):903-14. Available from: https://doi. org/10.1007/s00264-011-1443-z.

5. Khan M, Bedi A, Fu F, Karlsson J, Ayeni OR, Bhandari M. New perspectives on femoroacetabular impingement syndrome. Nature Reviews Rheumatology [Internet]. Springer Science and Business Media LLC; 2016 Mar 10;12(5):303-10. Available from: https://doi.org/10.1038/nrrheum.2016.17.

6. Jamil M, Dandachli W, Noordin S, Witt J. Hip arthroscopy: Indications, outcomes and complications. International Journal of Surgery [Internet]. Elsevier BV; 2018 Jun;54:341-4. Available from: https://doi.org/10.1016/j.ijsu.2017.08.557.

7. Colvin LA, Bull F, Hales TG. Perioperative opioid analgesiawhen is enough too much? A review of opioid-induced tolerance and hyperalgesia. The Lancet [Internet]. Elsevier BV; 2019 Apr;393(10180):1558-68. Available from: https://doi. org/10.1016/s0140-6736(19)30430-1.

8. Bekker A, Kloepping C, Collingwood S. Meloxicam in the management of post-operative pain: Narrative review. Journal of Anaesthesiology Clinical Pharmacology [Internet]. Medknow; 2018;34(4):450. Available from: https://doi.org/10.4103/ joacp.joacp_133_18.
9. Chen Y, Jobanputra P, Barton P, Bryan S, Fry-Smith A, Harris $\mathrm{G}$, et al. Cyclooxygenase-2 selective non-steroidal anti-inflammatory drugs (etodolac, meloxicam, celecoxib, rofecoxib, etoricoxib, valdecoxib and lumiracoxib) for osteoarthritis and rheumatoid arthritis: a systematic review and economic evaluation. Health Technology Assessment [Internet]. National Institute for Health Research; 2008 Apr;12(11). Available from: https://doi.org/10.3310/hta12110.

10. Ahmed M, Khanna D, Furst DE. Meloxicam in rheumatoid arthritis. Expert Opinion on Drug Metabolism \& Toxicology [Internet]. Informa Healthcare; 2005 Nov 30;1(4):739-51. Available from: https://doi.org/10.1517/17425255.1.4.739.

11. Yuan Y, Cui D, Zhang Y. Preemptive meloxicam achieves a better effect on postoperative pain control and similar tolerance compared with postoperative meloxicam in patients receiving arthroscopic knee surgery. Inflammopharmacology [Internet]. Springer Science and Business Media LLC; 2019 Jun 28;27(6):1091-100. Available from: https://doi.org/10.1007/ s10787-019-00614-4.

12. Hou J, Li W, Chen Y, Yang L, Li L, Zhao L. Early preoperative versus postoperative administration of meloxicam in pain control, patient global status improvement, knee function recovery of arthroscopic knee surgery. Medicine [Internet]. Ovid Technologies (Wolters Kluwer Health); 2019 Oct;98(40):e17133. Available from: https://doi.org/10.1097/md.0000000000017133.

13. Domb B, Hanypsiak B, Botser I. Labral Penetration Rate in a Consecutive Series of 300 Hip Arthroscopies. The American Journal of Sports Medicine [Internet]. SAGE Publications; 2012 Feb 28;40(4):864-9. Available from: https://doi. org/10.1177/0363546512437152.

14. Banaszkiewicz PA. Traumatic Arthritis of the Hip After Dislocation and Acetabular Fractures: Treatment by Mold Arthroplasty: An End-Result Study Using a New Method of Result Evaluation. Classic Papers in Orthopaedics [Internet]. Springer London; 2013 Dec 7;13-7. Available from: https://doi. org/10.1007/978-1-4471-5451-8_3.

15. Zhu X. Efficacy of preemptive analgesia versus postoperative analgesia of celecoxib on postoperative pain, patients' global assessment and hip function recovery in femoroacetabular impingement patients underwent hip arthroscopy surgery. Inflammopharmacology [Internet]. Springer Science and Business Media LLC; 2019 Oct 8;28(1):131-7. Available from: https://doi.org/10.1007/s10787-019-00648-8.

16. Turck D, Roth W, Busch U. A Review of the Clinical Pharmacokinetics of Meloxicam. Rheumatology [Internet]. Oxford University Press (OUP); 1996 Apr 1;35(suppl 1):13-6. Available from: https://doi.org/10.1093/rheumatology/35.suppl_1.13.

17. Penprase B, Brunetto E, Dahmani E, Forthoffer JJ, Kapoor S. The Efficacy of Preemptive Analgesia for Postoperative Pain Control: A Systematic Review of the Literature. AORN Journal [Internet]. Wiley; 2015 Jan;101(1):94-105.e8. Available from: https://doi.org/10.1016/j.aorn.2014.01.030.

18. Grape $S$, Tramèr MR. Do we need preemptive analgesia for the treatment of postoperative pain? Best Practice \& Research Clinical Anaesthesiology [Internet]. Elsevier BV; 2007 Mar;21(1):51-63. Available from: https://doi.org/10.1016/j. bpa.2006.11.004.

19. Gates BJ, Nguyen TT, Setter SM, Davies NM. Meloxicam: a reappraisal of pharmacokinetics, efficacy and safety. Expert Opinion on Pharmacotherapy [Internet]. Informa Healthcare; 2005 Oct;6(12):2117-40. Available from: https://doi. org/10.1517/14656566.6.12.2117. 
Обоснование предоперационного (или послеоперационного) назначения метоксикама для менеджмента острой боли и оценка удовлетворенности пациентов с фемороацетабулярными поражениями, перенесших операцию артроскопии тазобедренного сустава

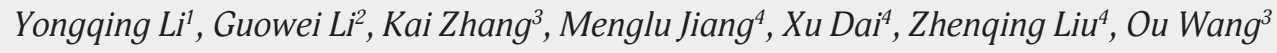

${ }^{1}$ Отделение анестезиологии, госпиталь Шанхай Лиц̧юнь, район Путуо, Шанхай, Китай

${ }^{2}$ Отдел анестезиологии Пятого народного госпиталя Уси при университете Цзяннань, Уси, Китай

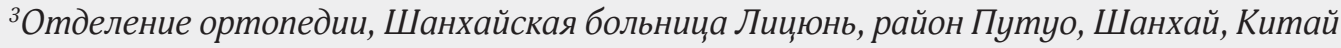

${ }^{4}$ Отделение анестезиологии Народной больницы № 9 Уси при Университете Сучжоу, Уси, Китай

\section{Аннотация}

Цель: это исследование было направлено на сравнение обезболивающего эффекта и безопасности предоперационного и послеоперационного введения мелоксикама у пациентов с фемороацетабулярным импиджментом (FAI), перенесших операциюю артроскопии тазобедренного сустава (НA).

Meтоды: всего было набрано 136 пациентов FAI, которым назначена НА, затем они были случайным образом распределены в группу предоперационного введения (PREA) (мелоксикам перорально 7,5 мг за 12 часов, за 24 часа до операциии, затем перорально 7,5 мг/день с 12 часов до 7 дней после операции;; $N=68)$ или группу послеоперациинного введения (POSA) (мелоксикам перорально 7,5 мг/сут с 12 часов до 7 дней после операциии; $N=68$ ) в соотношении 1: 1. Кроме того, проводилась оценка боли по визуальной аналоговой шкале (ВАШ), оценкка удовлетворенности пацииентов, оценка тазобедренного сустава Харриса (HHS) и побочные эффекты. Также было рассчитано накопленное потребление петидина для снятия анальгезии.

Результаты: оценка острой боли по ВАШ в покое (Day 1 - Day 2) и оценка боли по ВАШ при движении (Day 1 - Day 3) были уменьшены, в то время как краткосрочная оценка удовлетворенности пациентов (Day 1 - Day 3) была увеличена в группе PREA по сравнению с группой POSA; однако эти оценки в отдаленном периоде не различались между группой PREA и группой POSA (Day 3 - Month 3). Кроме того, накопленное потребление петидина на 3-й и 7-й день было снижено в группе PREA по сравнению с группой POSA. Tакже, HHS в любые оцененные временные точки (Day 7 - Month 3) не различались между двумя группами. Кроме того, не было обнаружено различий в частоте нежелательных явлений между двумя группами.

Заключение. Предоперациинное введение мелоксикама демонстрирует более высокую эффективность в краткосрочном купировании боли, улучшении удовлетворенности пациентов и меньшем потреблении спасательной анальгезии по сравнению с послеоперационным введением мелоксикама у пациентов с FAI, перенесших НА.

Ключевые слова: мелоксикам, фемороацетабулярный импиджмент, артроскопия тазобедренного сустава, эффективность, безопасность. 
Обгрунтування передопераційного (або післяопераційного) призначення метоксикаму для менеджменту гострого болю та оцінка задоволеності пацієнтів з фемороацетабулярними ураженнями, які перенесли операцію артроскопії кульшового суглоба

Yongqing $\mathrm{Li}^{1}$, Guowei $\mathrm{Li}^{2}$, Kai Zhang ${ }^{3}$, Menglu Jiang ${ }^{4}$, Xu Dai ${ }^{4}$, Zhenqing Liu ${ }^{4}, \mathrm{Ou}_{\text {Wang }}^{3}$

${ }^{1}$ Кафедра анестезіології, Шанхайська лікарня Ліц̨юнь, район Путуо, Шанхай, Китай

${ }^{2}$ Кафедра анестезіології, П’ята народна лікарня Усі при Університеті Цзяньнань, Усі, Китай

${ }^{3}$ Відділ ортопедії, Шанхайська лікарня Ліцюнь, район Путуо, Шанхай, Китай

${ }^{4}$ Кафедра анестезіології, Народна лікарня № 9 Усі при Університеті Сучжоу, Усі, Китай

\section{Анотація}

Завдання: цุе дослідження мало на меті порівняти знеболюючий ефект і безпеку передопераціійного та післяопераційного введення мелоксикаму у паціінтів з фемороацетабулярним ураженням (FAI), які перенесли операцію з артроскопії кульшового суглоба (НА).

Meтоди: загалом було набрано 136 хворих на FАI, яким запланували НА, потім їх випадковим чином розподілили до групи передопераціійного введення (PREA) (перорально мелоксикам 7,5 мг за 12 годин, 24 години до операцііі, потім перорально 7,5 мг/добу з 12 годин до дня 7 після операції; $N$ = 68) або групи післяопераціійного введення (POSA) (перорально мелоксикам 7,5 мг/добу з 12 год до дня 7 після операції; N = 68) у співвідношенні 1 : 1. Крім того, оцінювали оцінку аналогової шкали болю (VAS), оцінку задоволеності паціієнтів, оціінки кульшовго суглоба Харріса (HHS) та побічні ефекти. Також було розраховано накопичене споживання петидину для менеджменту знеболення.

Результати: оцінка гострого болю VAS у стані спокою(Day 1 - Day 2) та оцінка VAS болю при русі (Day 1 Day 3) була зменшена, тимчасом оціінка короткочасного задоволення пацієнтів (Day 1 - Dау 3) була збільшена в групі PREA порівняно з групою POSA; однак изі показники протягом довгострокового періоду не мали різниці між групою PREA та групою POSA (Day 3 - Month 3). Крім того, накопичене споживання петидину на День 3 та День 7 було зменшено у групі PREA порівняно з групою POSA. Крім того, HНS у будь-який оцінений часовий момент (Day 7 - Month 3) не відрізнявся між двома групами. Крім того, не виявлено різниці у частоті побічних явищ між двома групами.

Висновок: передопераційне введення мелоксикаму демонструє чудову ефективність при короткостроковому контролі болю, поліпшення задоволеності пацієнтів та зменшене споживання рятувальної анальгезії порівняно з післяопераційним введенням мелоксикаму у паціієнтів з ІАП.

Ключові слова: мелоксикам, фемороацетабулярне ураження, хірургічна артроскопія кульшового суглоба, ефективність, безпека. 